ISSN: $1984-2201$

Copyright @ 2002, Universidade Federal do Ceará

\title{
LANDSCAPE THEORY APPLIED TO THE CHOICE OF AREAS FOR LANDFILLS
}

\author{
OLIVEIRA, Rodrigo Coladello; ${ }^{*}{ }^{*}$ BOIN, Marcos Norberto; ${ }^{b}$ FELICIO Munir Jorge ${ }^{\mathrm{c}}$
}

\begin{abstract}
(a) Msc. in Environment and Regional Development, University West of São Paulo. http://lattes.cnpq.br/5913622361173546
(b) Phd in Geoscience Lecteur State University of São Paulo Júlio de Mesquita Filho (UNESP). http://lattes.cnpq.br/3296065409205193

(c) Phd in Geography, Lecteur University West of São Paulo. http://lattes.cnpq.br/2736278317059093
\end{abstract}

\section{(*) CORRESPONDING AUTHOR}

Address: Avenida José Libânio Filho, n 346. CEP: 19067-170, Presidente Prudente (SP), Brasil. Tel: (+55 18) 32292060

E-mail: coladelloengenharia@gmail.com

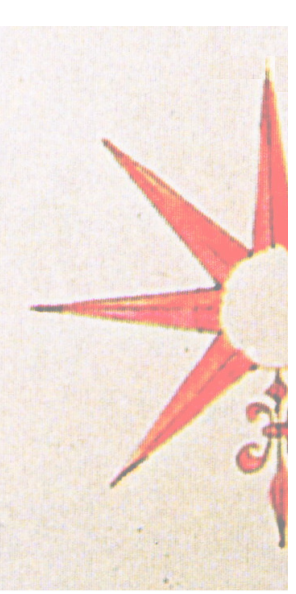

\begin{abstract}
This paper aims to create a proposal for methodological adaptation of planning, which subsides to a new model of analysis and choice of locations with geoecological potential for installing landfills in the city of Anhumas in the Western Plateau of São Paulo State. Hence, we used Landscape Theory, based on the systemic approach. The importance of this proposal lies in the fact that Anhumas is part of one of the areas most impacted by effluent percolation on porous soils in São Paulo State, showing high levels of environmental fragility in the face of porous soils from the sandstone rocks that make up this region. However, there are no studies that incorporate natural systems to anthropic systems in planning the choice of areas for solid waste landfills. For this purpose, we adopted the methodology for the study and planning of the landscape highlighting the functional diagnostics, weaknesses and intrinsic potential.
\end{abstract}

Keywords: Physical Geography; Solid Waste; Geomorphology; Environmental Planning.

\section{RESUMO/RESUME}

\section{TEORIA DA PAISAGEM APLICADA À ESCOLHA DE ÁREA PARA ATERROS SANITÁRIOS}

Este artigo objetivou elaborar uma proposta de adaptação metodológica de planejamento, que sirva de subsídio para um novo modelo de análise e escolha de locais com potencialidade geoecológica à instalação de aterros sanitários no município de Anhumas - SP, situado no Planalto Ocidental Paulista. Para tanto, utilizou-se a teoria da paisagem, baseada na abordagem sistêmica. A importância desta proposta está no fato do município de Anhumas fazer parte de uma das áreas mais impactadas pela percolação de efluentes sobre solos porosos no estado de São Paulo, apresentando altos níveis de fragilidade ambiental em face aos solos porosos oriundos das rochas areníticas que constituem esta região. No entanto, não existem estudos que integrem os sistemas naturais aos sistemas antrópicos no planejamento para a escolha de áreas para aterros de resíduos sólidos. Para atingir tal desígnio, adaptaram-se metodologias para estudo e planejamento integrado da paisagem, destacando o diagnóstico funcional, fragilidades e potencialidades intrínsecas.

Palavras-chave: Geografia Física; Resíduos Sólidos; Geomorfologia; Planejamento.

\section{THÉ ORIE DU PAYSAGE APPLIQUEE AU CHOIX DES ZONES POUR SITE D'ENFOUISSEMENT}

Ce travail a comme but l'élaboration d'une proposition de 1\&\#39; adaptation méthodologique de planification que puisse servir comme une subvention pour un nouveau modèle $\mathrm{d} \& \# 39$; analyse et de choix des sites à fort potentiel géo-écologiques pour 1\&\#39;installation d\&\#39; enfouissements sanitaires dans la ville de Anhumas - SP, située dans le Plateau occidental Paulista. Pour cela on a utilisé la théorie du paysage, basé sur 1\&\#39;approche systémique. L\&\#39;importance de cette proposition c'est dans le fait que la ville de Anhumas fait partie d'une des zones les plus impactées par la percolation des effluents sur les sols poreux de 1\&\#39;état de São Paulo, ce qui présente hauts niveaux de fragilité environnementale face aux sols poreux, résultant de roches de grès qui composent cette région. Cependant, il n\&\#39; y pas d\&\#39;études qui intègrent les systèmes naturels aux systèmes anthropiques dans la planification pour le choix des sites de décharges de déchets solides. Pour atteindre ce but, on a adopté les méthodologies pour 1\&\#39;étude et planification du paysage, soulignant le diagnostic fonctionnel, les faiblesses et les potentialités intrinsèques.

Mots Clés: Géographie Physique; Déchets Solides; Géomorphologie; Planification Environnementale. 


\section{INTRODUCTION}

The concept of landscape as a scientific-geographical term was initially given by the German Alexander Von Humboldt (1769-1859), considered the pioneer of geobotany and physical geography of the Germanic school. The term landscape derives from the German Landschaft, which unlike pictorial and literary landscapes, connote the geographic-spatial meaning of the term (TROPPMAIR, 2004). According to Naveh (1991), the concept of a vertical landscape refers to all the elements that constitute and act in it, from the atmosphere to the mother rock, through vegetation, soil, surface water and groundwater. In view of this, Mateo Rodriguez et al. (2004) present a series of conditions that generate the landscape, such as: geology, climate, relief, water, and edaphic and biotic factors. It is understood that the integration of these constraints corresponds to the landscape geoecology, which for Naveh and Lieberman (1984), is considered as scientific support for the study and planning of the landscape. In this sense, Santos (2004), in his work on environmental planning, ponders that landscape ecology (or geoecology of the landscape) provides an integrating support in the analysis of the elements that act in the environment, besides leading to their observation and systematization.

The integration of territorial constraints is necessary in view of the expansion of solid waste generation and the scarcity of areas for the final disposal of waste, especially in areas of sedimentary and porous soils. Since not all areas that contribute to the support of natural resources may be suitable for the installation of waste landfills, it is advisable to use objective technical and scientific criteria to prioritize them. Numerous studies highlight the importance of selecting areas following methods that allow the evaluation of different portions of the space considered adequate for the disposal of waste, without causing environmental degradation.

Regarding the west of São Paulo, it is interesting to observe how the implantation of landfills has always occurred without the proper planning that takes the environmental issues into account. The environmental fragility in porous environments is quite high and the changes in these environmental systems due to anthropic action cause irreversible damage. Also in this region, damage to environmental systems, especially water resources, can be identified in almost all municipalities, completely changing water quality indices, which triggers changes in aquatic ecosystems, among other environmental problems. Consequently, these changes in the natural environment affect the local population's quality of life and the provision of the environmental services necessary for their survival. It is important that the legal norms that govern quality and environmental standards take into account not only the technical-economic aspects of the projects, but also the geoecological characteristics of the area, its potential and fragility.

The objective of this work is to propose a methodological adaptation of planning according to landscape theory and based on the systemic approach, which serves as a subsidy for a new analytical model to analyze and select sites with geoecological potential for the installation of landfills. The following specific objectives were defined: a) To elaborate a geoenvironmental inventory of the municipality of Anhumas, on a scale of 1: 100,000; b) To draw up a geoenvironmental plan of the municipality to identify and map the weakness and potentialities for the installation of a landfill; c) To follow governmental policies and actions directed towards the environmental management of solid residues, in the federal, state and municipal spheres; and d) Construct an environmental diagnosis of the municipality in question, based on the environmental units indicated by the analysis of the results of the Inventory step.

A study carried out in accordance with the geoecology of the landscape, proposed through a systemic approach for the municipality of Anhumas, is important, first, because this part of the west of São Paulo is one of the areas most impacted by the percolation of effluents on porous soils. Secondly, both the region and the municipality of Anhumas have not shown due care with the implementation of waste landfills, failing to consider the levels of environmental fragility of the areas selected, accentuating environmental problems. Furthermore, there are no studies that integrate na- 
tural systems with anthropic systems when planning for the choice of areas for solid waste landfills, which in recent years has become a major global concern. Thus, it is possible to contribute to the elaboration of measures for the allocation and use of the space, in order to minimize the impacts that can cause environmental damage.

This paper presents a proposal for the application of landscape geoecology, aiming at planning the choice of area for the final disposal of solid waste, which, based on a sectoral and holistic evaluation, integrates the landscape's conditioning factors in its analysis. The methodological adaptation of landscape theory allowed, for example, the verification of areas with different degrees of environmental fragility for the implantation of landfills. Such an analysis must be supported by a geotechnical characterization, even in those landscape units less suited to the implantation of landfills, so that damage to the water resources and the different environmental systems is minimized and controlled.

\section{STUDY AREA}

The municipality of Anhumas is located in the western portion of the state of São Paulo, in the Presidente Prudente region, occupying an area of $320 \mathrm{~km} 2$, the coordinates of the central point of the city are: $22^{\circ} 17$ ' 45 "S (Latitudinal) and 51 $23^{\circ}$ ' $08^{\prime}$ " W (Longitudinal), located in part of the Paulista Western Plateau (Figure 1).

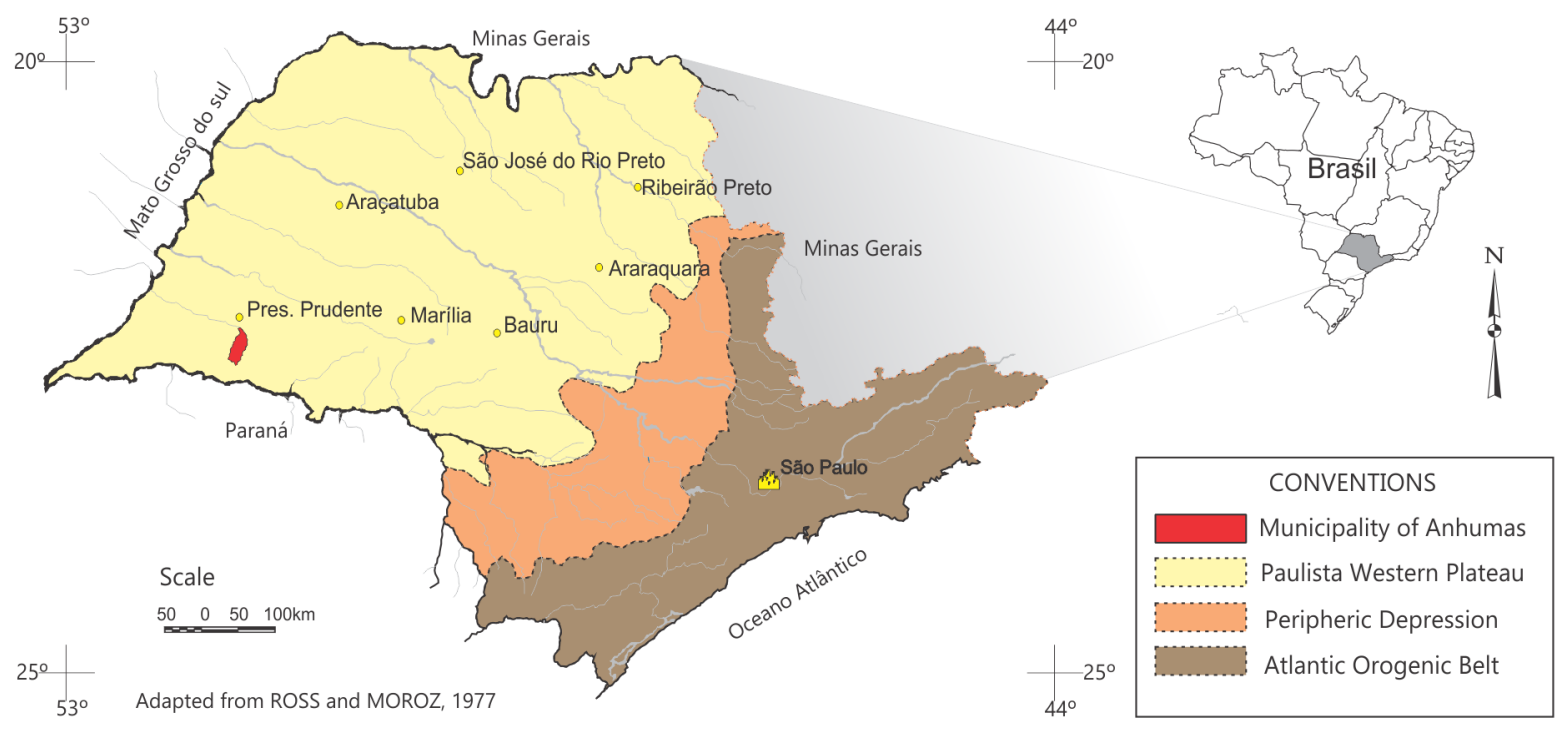

Figure 1 - Location of the municipality of Anhumas, in the state of São Paulo.

In the landscape of the municipality of Anhumas, the relief has a monotonous hilly aspect with a low occurrence of movement, represented by ruptures in the relief, controlled by the different lithological facies of the sedimentary rock substrate of the Paraná basin, of Cretaceous age, conceived by the Adamantina Formation, mapping units of Kal, KaIV and KaV (ALMEIDA, et al. 1980) and fluvial, trough or terrace unconsolidated quaternary sediments. The northern portion presents the most rugged relief of medium hills, with interfluves with an area of 1 to $4 \mathrm{~km}$, flattened tops and convex, convex and rectilinear slopes ( $5 \%$ to $>10 \% \mathrm{decl}$.), corresponding to the mapping units $\mathrm{KaIV}$ and $\mathrm{KaV}$. In the southern sector the relief is flat, with large interfluvial hills, with an area of more than $4 \mathrm{~km}$, extensive and flattened tops and slopes with concave and convex profiles ( $0 \%$ to $10 \%$ decl.), located in mapping unit KaI., influenced by the sandy sediments of the Adamantina Formation and the relief in the study area, Red-Dark Latosols occur on the tops of the hills, on the 
middle slope there are Red-Yellow Argisols, in the relief ruptures there are Littoral Neosol / Littoral Neosol submitted to hydromorphism and Alaskan Quartz Sands on the valley bottoms.

Even with the municipality's low geological and geomorphological diversity, these aspects directly affect the physiognomic variations of the vegetation. The Atlantic Forest remained in its natural state until the beginning of the occupation process, when the forest with its different physiognomies covered the entire west of São Paulo state. At the beginning of the twentieth century, disordered deforestation reduced the forest area to $1.13 \mathrm{~km}^{2}$, corresponding to $3.49 \%$ of the original quantity in the municipality. Today, remnant fragments of secondary vegetation of semi-deciduous seasonal forest are recorded in the slopes of medium hills, on shallow soils in the northern portion of the municipality, while in the southern portion, in an area of broad hills with deep soils, are the remnants of cerrado vegetation. At the bottom of the valley and in the groundwater areas of the medium slope, there is vegetation adapted to the wetlands, with typical hydrophilic species. The municipality's vegetation is very degraded, leaving a few fragments of primary or secondary native vegetation in restricted portions of the slopes or those protected in the surroundings of the water resources. Still in protected areas, the occurrence of this vegetation is fragmented and it shares space with areas of pasture present in almost every municipality. The most common agricultural crop is sugar cane, distributed mainly on the flat relief, as opposed to rugged relief areas, in which different types of food crops are cultivated temporarily and are also used for pasture and forestry.

\section{MATERIAL AND METHODS}

The theoretical framework of the present work is based on landscape theory, using the systemic approach as a paradigm. In order to do so, we sought work on landscape interpretation, ecology, ecosystem, ecodynamics, general systems theory and geoecology, based on the works of Von Bertalanffy (1950), Christofoletti (1972), Tricart (1977), Bertrand \& Bertrand (2002), Bertrand (1995; 2004), Guerra \& Marçal (2012), Mateo Rodriguez $(2000,2006)$ and Mateo Rodriguez et al. (2004, 2006). To complement the theoretical structuring of the landscape, our study also relied on other authors who work with planning methodologies such as: Oliveira (1983), Bergamo \& Almeida (2006), Nucci (2009), Ross (2012) and Santos (2004). After this, to give context to the research, a review was carried out of Works on the theme of solid waste, landfills and attributes for choosing locations, noteworthy studies were by Zuquette; Pejon \& Sineli (1994), Leite (1995), Leite \& Zuquette (1996), Tressoldi \& Consoni (1998), Nunes (2002), Montaño et al. (2012) and Boscov Gimenez (2012). This methodology consisted of the organization of the inventory and the elaboration of an environmental diagnosis and prognosis. Once this was completed and the legal restrictions to the territory of the municipality had been applied, a map of the legal restrictions was produced, which allowed the comparison with the characteristics of the physical environment and its interrelations with the restrictive components.

The integrated set of this information helped the inductive phase. The evaluation of the results of the environmental characterization supporting the diagnostic phase is a summary of the studies, as they present the main environmental problems, allowing the characterization of the geoenvironmental panorama.

Based on the aforementioned methodological basis for the construction of this environmental planning proposal, it was necessary to prepare cartographic documents, emanating from the synthesis and interpretation of other maps.

In order to determine environmental fragility, the model proposed by Ross (1994) - based on the ecodynamic and ecosystem concepts previously defined by Tricart (1977) (Table 1) - was adapted to determine potentially unstable ecodynamic units (stable) and emerging instability (unstable), classified by degrees of fragility (Figure 2). 
Table 1 - Relationship between the concepts of natural and anthropic environments, defined by ROSS (1994) and TRICART (1977)

\begin{tabular}{c|c|c|c}
\hline \multirow{2}{*}{ AUTHORS } & \multirow{2}{*}{$\begin{array}{c}\text { METHODOLOGICAL } \\
\text { PROPOSAL }\end{array}$} & CONCEPT \\
\cline { 3 - 4 } & NATURAL ENVIRONMENTS & ANTHROPIZED ENVIRONMENTS \\
\hline TRICART, 1977 & Ecodynamics & Stable units & Unstable units \\
\hline Ross, 1994 & Environmental Fragility & $\begin{array}{c}\text { Ecodynamic units of potential } \\
\text { instability }\end{array}$ & Ecodynamic units of emerging instability \\
\hline
\end{tabular}

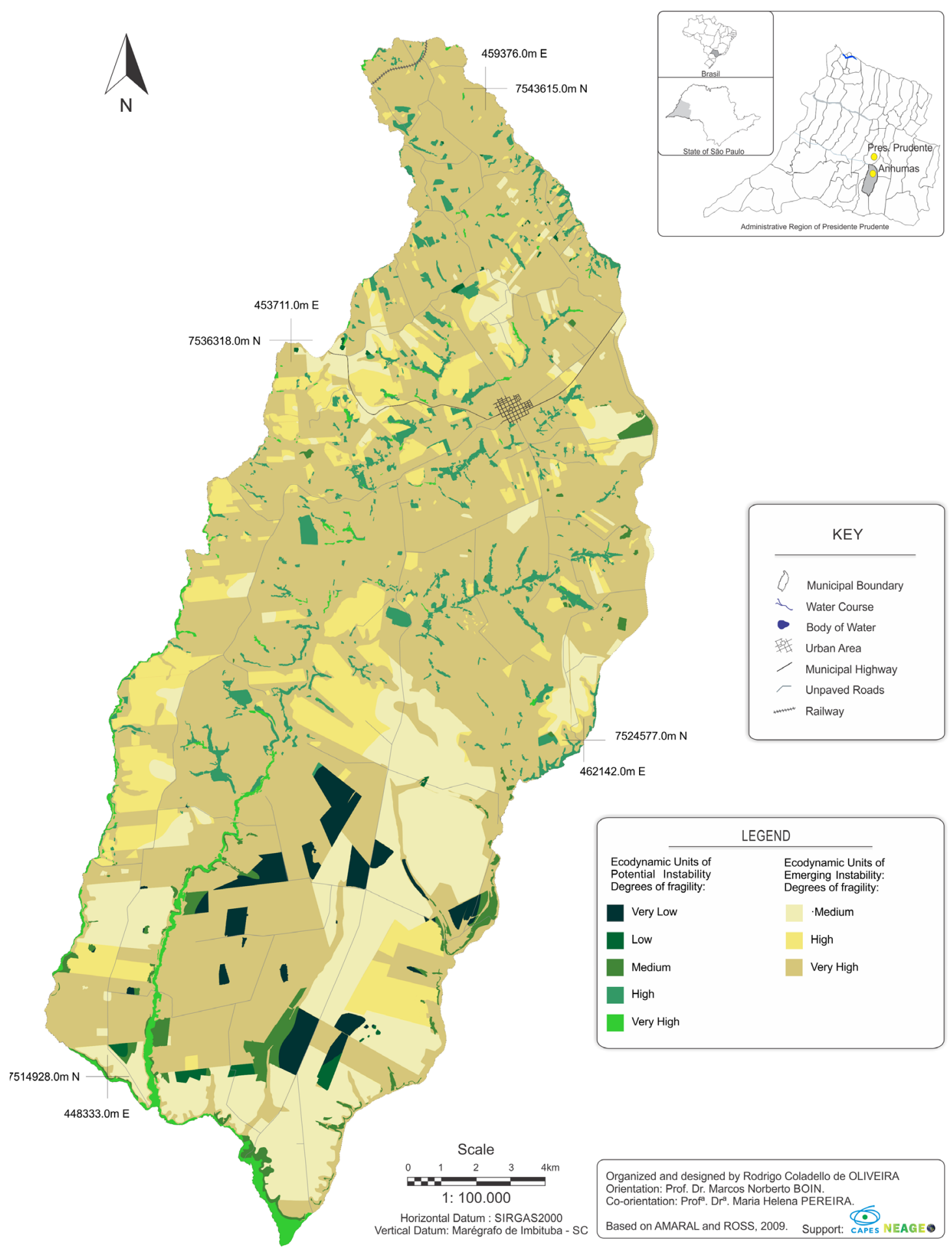

Figure 2 - Map of ecodynamic units of potential and emerging instabilities 
Thus, the ecodynamic units of potential instability are those in which the dynamic equilibrium is in its natural state but there is potential instability, due to possible anthropic intervention. On the other hand, the ecodynamic units of emergent instability are presented as natural environments that at one time were intensely altered by anthropic activities of several genera. In order to obtain the classification of the ecodynamic units and the potential / environmental fragility, four factors were surveyed and evaluated according to the parameters determined in Ross (1994) and Amaral and Ross (2009): land use / vegetation cover, relief, soil and climate. These elements were integrated "two by two", as proposed by Santos (2004), composing a matrix of correlation and the creating a chart of ecodynamic units of potential and emerging instability (Figure 2).

The attributed levels of fragility restrict the installation of the landfill in ecodynamic units of potential instability, due to their main characteristic of an environment with preserved native vegetation or in a stage of advanced regeneration. This leaves only those with emerging instability, but which still require an evaluation of their feasibility for use prior to installation.

Thus, five classes of potential environments of ecodynamic instability and three classes of ecodynamic environments of emergent instability were obtained (Figure 2), in which, given the need considered for the preservation of vegetation units, the former become unfeasible. In the second, the levels of environmental fragility range from medium (3) to very high (5), which reduces the locational possibilities of greater suitability for landfill implantation, since these units are subject to anthropic use, which, allied to the intrinsic characteristics of the environment's fragility and the absence of conservation management practices, promptly promote the degradation of the environment.

The physical attributes of the municipality were considered when mapping the landscape units (Figure 3), such as: lithology, relief, soils, vegetation and climate, as well as morphometric aspects, such as altimetric levels and declivity. Added to these physical attributes, the integration of land use and geotechnical-legal constraints were also considered. The landscape units also result from the "two by two" method of overlapping information, according to Santos (2004), in which the cartographic data were integrated.

The nomenclature of each unit was correlated with the lithological mapping units, the predominant relief forms, added to the active pedogenetic processes, climatic type, natural vegetation cover and land use, considering the degree of dominant fragility of each of these attributes. Such a map (Figure 3) made it possible to cover all the dynamics of the natural processes and to identify the areas with environmental fragility directed to the implantation of the waste landfill.

The summary chart of legal restrictions (Figure 4) was developed based on the legislation and regulations that restrict the installation of landfills in certain environments, whether due to socio-environmental aspects or for safety reasons.

Thus, the legal restrictions used in this research were: Permanent Preservation Areas (Metzger's academic contribution (2010), which recommends Areas of Permanent Preservation be at least 50 meters away from water resources, was considered for the delimitation of this restriction); Ministerial Order MINTER 124/1980 (predicts that activities with high contamination power will be kept at least 200 (two hundred) meters away from any accumulated water); Airport Security Area - CONAMA 04/1995 (restricts undertakings of this category within a radius of twenty (20) kilometers from the geometric center of any adjacent aerodrome, in this case the state airport of Presidente Prudente - SP); Restriction of high voltage grids - ABNT / NBR 5422/1985 (establishes a band range of 15 (fifteen) meters from the high voltage grids, therefore, this band was considered a restrictive element); Distance of housing settlements (according to CETESB recommendations (1994) a minimum distance of 2 (two) kilometers from any population is required, avoiding, in this way, possible social and economic problems); and a minimum distance of 200 meters from highways. 


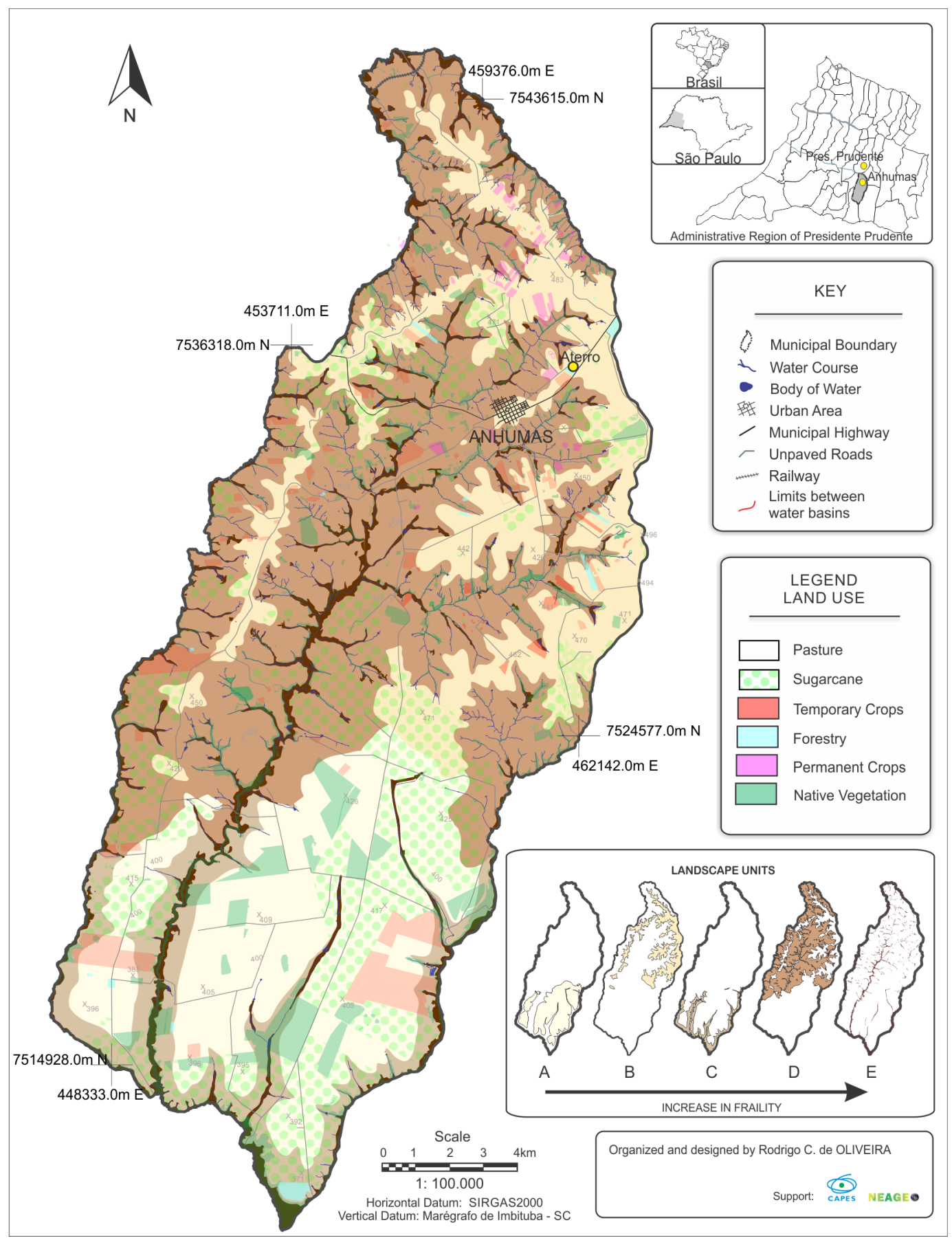

Figure 3 - Map of landscape units and their respective fragility 


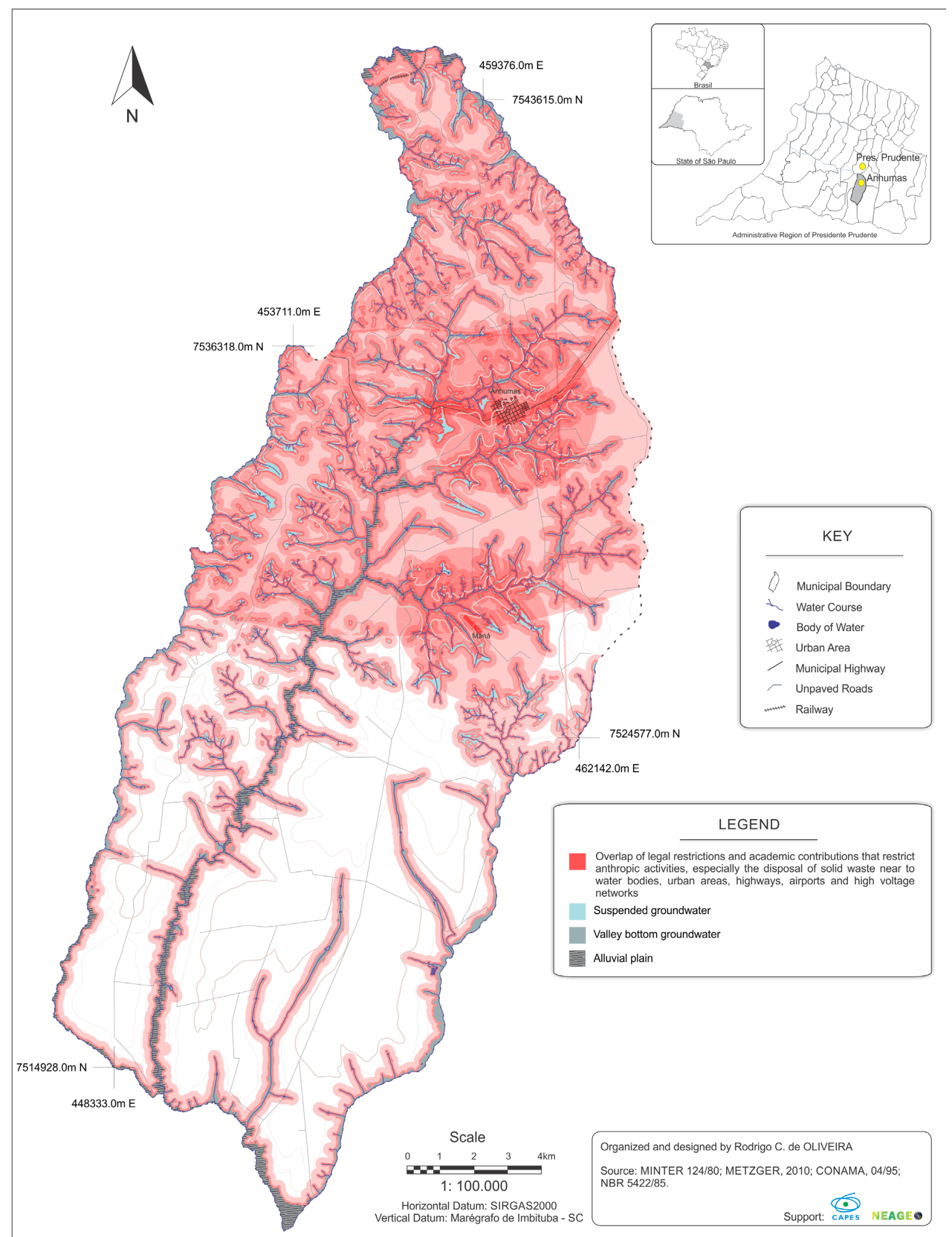

Figure 4 - Map of legal restrictions to the implantation of waste landfill 


\section{RESULTS AND DISCUSSION}

The proposal of environmental planning based on the theory of landscape geoecology, with the purpose of evaluating the suitability of the installation of waste landfills, delimited five zones defined as ecodynamic units of potential instability and three of emergent instability (TRICART, 1977, ROSS, 1994, AMARAL \& ROSS, 2009), which define zones with degrees of environmental fragility in the municipality of Anhumas (Figure 2).

It is worth mentioning that the vegetation existing in the ecodynamic environments of potential instability, once presented by Tricart (1977) as "stable environments", is able to maintain morphogenetic stability and, in certain situations, act as sensitive sites for anthropic interventions; they range from stable to intergrade, returning to stable again or rapidly advancing to unstable. Ross (1994) echoes Tricart's (1977) conceptions of ecodynamics and also ponders that anthropogenic interventions cause changes in the flows of energy and matter in systems that are in dynamic equilibrium, so they must necessarily be protected. Examples of this are places where the arboreal vegetation maintains the stability of the slopes, sustaining the dynamic balance between the flows of matter and energy and consequently controlling the erosive processes, according to the ecodynamic units of potential instability. Regarding this unit, its main characteristic is the existence of native tree vegetation in different conservation states.

The units of potential instability in the municipality of Anhumas, composed of remnants of secondary vegetation in different stages of regeneration, are established under specific soil conditions related to soil layer thickness and groundwater depth. In general, the Atlantic Forest biome is located in the north, where the soil thickness is less deep and the water table has shallow local sheets, the vegetation fragments correspond to the physiognomy of the Semideciduous Seasonal Forest, while to the south, where the soil is deep and the local water table is not very accessible, the physiognomy of the cerrado occurs.

With environmental potentiality and a vocation of use, vegetation accommodates ecosystemic and biodiversity potential, providing a dynamic balance between energy, matter and information flows. It has a great role as a landscape and actively contributes to recharging the regional water table. The fragility and environmental aspects of these units are related to soils with low fertility, but the existing vegetation is responsible for maintaining the nutrient cycle. The suppression of the vegetation cover can trigger erosive processes, which are common in this region due to the excessive soil fragility. In view of the low coverage of native vegetation and the environmental service that it exerts in filtering the contaminants discarded on the soil, the use of these parts of the landscape for the disposal of solid waste highly restricts their installation or any other activity that may dispose of percolates on the soil (OLIVEIRA, 2015). Thus, the main characteristics of the ecodynamic units with potential instability are related to the possibility of contaminating water resources (superficial and sub-surface), provided by the horizontal and vertical distance of this resource, and also by the thickness of the soil and its position in the relief, see Table 2, below. 
Table 2 - Distinguishing features of the degrees of fragility of the ecodynamic units with potential instability (Figure 2)

\begin{tabular}{c|c|c|c}
$\begin{array}{c}\text { DEGREE OF FRAGI- } \\
\text { LITY }\end{array}$ & RELIEF & SOILS & HYDRIC POTENTIAL \\
\hline Very Low & Flat tops & Latosols (deep) & Low \\
\hline Low & Straight slopes, convex hill tops & Argisols and Lotosols (Average depth) & Low \\
\hline Medium & Convex hill tops & Argisols and Lotosols (Average depth) & Low \\
\hline High & Convex concave slopes (high slope) & Argisols (low depth) & High \\
\hline Very high & Vale bottom relief & Hydromorphic Soils (on the water table) & $\begin{array}{l}\text { Outcropping of water table } \\
\text { on valley bottom and slope }\end{array}$
\end{tabular}

The three ecodynamic units of emergent instability found in the Anhumas territory, have the following characteristics:

Medium (Figure 2). This unit is characterized by extensive areas of sugarcane cultivation and restricted areas of permanent cultivation and forestry. The flat-topped relief provided by the mapping unit KaI, contributes to the mechanized management of sugarcane and, consequently, to the spatial expressiveness of this crop. In some sectors, sugarcane cultivation advances along the straight slopes towards the valley bottoms of the municipality's main watercourses (Ribeirão Anhumas and Córrego da Onça). When in Argisols and interfluvial convex tops, the polygons of this unit become reduced.

High (Figure 2). A unit characterized by areas of sugarcane cultivation and restricted areas of permanent and temporary cultivation and forestry, especially when located on flat or rectilinear tops and Latosol. Convex concave slope and Argisols predominate in the relief, with mosaics of permanent and temporary cultivation and forestry inferior in size to the sugarcane. In some sectors, sugarcane farming advances towards the valley bottom of the Anhumas, São Pedro, Córrego do Cambui and Córrego da Onça rivers.

Very high (Figure 2). A unit characterized by extensive areas of pasture and soils in preparation for planting, in addition to restricted areas, with marsh and fallow vegetation. This unit is the most comprehensive of the municipality, commonly found on fluvial plains, rectilinear convex slopes, convex concave slopes, convex tops, flat tops, in Latosol, Argisols, Hydromorphic and Litolic Neosols soils. In some sectors of mapping units $\mathrm{KaIV}$ and $\mathrm{KaV}$ there are hydrogeological features reflected on the surface of the terrain (suspended sheets) associated with steep slopes, as well as advanced erosive processes and others already obliterated. In these units of medium, high and very high fragility, the vegetation cover controls the erosive processes and the agropastoral activities can be exercised if associated with sustainable management. The landfill site should be subject to effective management and safety techniques, according to the degrees of fragility, since the greater permeability of the soil may contribute to the contamination of the regional water table in atypical circumstances of leakage of contaminants.

Therefore, landfill sites in locations like the above, together with the absence of soil conservation practices, may compromise the geotechnical stability of the project, especially in porous environments, where the soils formed lack cohesion and have low particle aggregation, thus favoring erosive processes.

In view of the low biodiversity, low density of native tree vegetation and the absence of riparian forests in these Units of Emergent Instability it is recommended that: 
1. In urbanized areas or even urban expansion, carrying out basic infrastructure projects, such as street paving, installing basic sanitation (water network and sewage) and performing maintenance on paving and sanitation systems, as well as garbage collection, removing the waste from the culverts and canals, and implementing the selective garbage collection, encouraging the creation of a cooperative of waste pickers and a recycling plant;

2. Agricultural environmental systems that have sugarcane farming as their main economic activity, as well as small plantings that use pesticides and chemical fertilizers, should control their application both in the soil and in the air, in addition to avoiding contamination by waste and effluents that may compromise the quality of surface water and groundwater;

3. Buffer zones foreseen by law to protect environmental systems and water resources are areas that need environmental care. This suggests the restoration of these systems in order to increase the native tree cover and the sustainability of the activities in the municipality;

4. To avoid the depletion of the productive potential of soils and also a deficit of water resources in the region, it is recommended that soil conservation techniques be applied in all agricultural activities, especially in areas destined to livestock.

\section{LANDSCAPE UNITS OF THE MUNICIPALITY OF ANHUMAS}

Based on the assumption that through the geoecological approach landscape theory provides an integrative theoretical and methodological foundation for environmental planning (MATEO RODRIGUEZ, 2004), it is possible to understand the behavior and dynamics of the natural environment, to point to specific diagnoses and structure strategies that optimize land use in line with its ability to support environments. Following this, the integration of natural and anthropic factors and technical or legal constraints to the installation of the landfill, led to three charts of the landscape units (Figure 3) with polygons of denomination and exclusive territorial areas, whose distribution criterion are not restricted just to homogeneity, but in fact to the inseparability of the elements - mentioned previously by the authors who worked with landscape theory -, the intensity of the interrelationships and historic evolution.

Although it is similar to the fragility approach, the synthesis of the landscape units is the final result of the research, which can be applied not only to the primary objective of this work, but also to municipal environmental planning and as an instrument to aid decision making for the installation of enterprises with a high capacity of contamination.

In this way, the model of integrated analysis of the landscape developed by Mateo Rodriguez et al. (1995), Mateo Rodriguez (2004), Bertrand (2004), among others, has contributed greatly to the identification of areas suitable for the installation of landfills.

In all, five landscape units were demarcated, which are a product of the integration between geology, relief, land use and land cover, which made it possible to analyze the particularities of each unit. The landscape units are organized sequentially according to their suitability for the installation of the landfill, being A (adequate), B (suitable with restrictions), C (restricted), D (inadequate) and E (severely restricted).

Unit A - In lithology of the informal Kal mapping unit of the Adamantina Formation, without hydrogeological features reflected on the surface, characterized by flat-topped relief and Dark Red Latosol. This unit is notable for its flat landscape with a mosaic of large rural properties, sugarcane cultivation, artificial pasture grasses and, secondarily, temporary crops and forestry, isolating the largest fragments of native vegetation that occur in the municipality. In this unit, 
the deep Latosols provide a greater suitability for the installation of the landfill, due to both the other geoecological aspects and the legal / technical restrictions.

Unit B - In lithology of the informal Kal and KaV mapping unit of the Adamantina Formation, without occurrence of hydrogeological features reflected in the surface, characterized by convex-topped relief and Red Yellow Argisols. It is important to point out the busy relief with a mosaic of small rural properties, where temporary and permanent crops predominate, as well as pasture grasses. The urban network of Anhumas is part of this unit, and fragments of native vegetation are scarce. In this unit, the Argisols are more developed than in the adjacent ones and the convex-topped relief allows greater infiltration of the percolating liquids in the soil. These are places where landfill installation is adequate with restrictions, since almost all the unit is under the Airport Security Area of Presidente Prudente - SP, only a small portion remains in the center-south portion of the municipality, which because it is located in an environment where the surrounding area is marked by high dissection, geotechnical safety measures must be applied to ensure the safety of the landfill if it is to be implanted.

Unit C - In lithology of the informal Kal mapping unit of the Adamantina Formation, without hydrogeological features reflected in the surface, except in isolated sectors, near the valley bottoms. It is characterized by rectilinear slopes and Red Yellow Argisol and Red Latosol soils. The rectilinear and generally sloped relief favors the planting and management of some crops, such as sugarcane and other temporary crops. These crops are found in large mosaics alternated with some fragments of native vegetation, as well as artificial pasture grasses. In this unit, the soils are well developed and in some sectors the relief is relatively flat, however MINTER Ordinance 124/1980 restricts the installation of the sanitary landfill to 200 meters from the water bodies, which significantly reduces the locational alternatives in this unit. As for the rest, which would be suitable for the installation of the landfill, the depth of the regional water table needs to be checked through surveys to ensure the safety of the enterprise, the environment and the health of the population.

Unit D -In lithology of the informal KalV and KaV mapping unit of the Adamantina Formation, with frequent intercalation of sandy and silty-clay banks that condition the hydrogeological features reflected on the surface, mainly in sectors of half slope. It is characterized by a busy relief, marked by concave and convex slopes and slope ruptures that provoke the exposure of the suspended water table. The busy relief and high slopes of some sectors control the land use in mosaics of a reduced size, where pasture grasses and sugarcane predominate and in smaller proportions temporary and permanent crops and forestry. Part of the city's urban network is in this unit, in addition to fragments of native vegetation along the valley bottoms of the municipality's main water bodies. In this unit, the soils are relatively underdeveloped and Littoral Neosols associated with high slopes and the outcrop of the underground water resource are common. As a result, there are sectors of this unit that present strong restrictions to the installation of the sanitary landfill, in accordance with MINTER Ministerial Decree 124/1980, in addition to others such as the Airport Security of Presidente Prudente, the distance of population clusters, highways and high voltage networks. By subtracting the restricted areas from the locational alternatives, there remains only a small portion of the center-south of the municipality that can be considered as a probable option for the installation of the landfill, but a more detailed approach to the technical and geoecological aspects are still required.

Unit E - In quaternary deposits on the sandstones of the Adamantina Formation, this unit has a flat relief and soils subordinated to the hydromorphism. In the drainage network, which covers the areas belonging to the informal mapping units $\mathrm{KIV}$ and $\mathrm{KaV}$, there are bands of structural 
lineaments of the NO-SE quadrant, called Guapiara or Presidente Prudente, and derivations of both. The humid environments in this unit favor species of marsh vegetation and hinder some forms of land use. This unit is considered as severely restrictive to the installation of landfill because it is located in places where the environmental conditions of fragility, associated to anthropic interventions can cause an intense dynamic imbalance between the flows of matter and energy in this ecosystem. In this sense, the impacts caused in this unit are reflected in the water resources and, therefore, there is a need to protect these environments as established by Ministerial Decree 124/1980.

When analyzing the restrictions on the area of the municipality, it is verified (Figure 4) that the northern sector has the greatest overlap of legal restrictions (MINTER Ordinance 124/1980, Airport Security Area - CONAMA 04/1995, restriction of high voltage networks - ABNT / NBR $5422 / 1985$ and distance from housing clusters). This overlapping coverage corresponds to $68 \%$ of the total area of the municipality, which indicates a high percentage of legal restriction. This fact demonstrates that in establishing the regulations imposed by legislation, there are few possibilities for areas to install landfills. In addition to the legal restrictions, it must still be considered that the physical environment, as presented above, offers different levels of fragility, which determine other restrictions of use.

The restriction to the north of the municipality is due, in part, to the characteristics of the physical environment, which has a higher density drainage network and numerous suspended groundwater, in addition to limited interfluves. The population centers are also located in this section, such as the city of Anhumas and the settlement of Maná, in addition to the high voltage networks, highways and the Airport Security Area.

However, to the south of the municipality, the absence of several of these factors, such as population clusters, airport security, highways and a physical environment with fewer water bodies, offers better conditions for the installation of sanitary landfills. It should be noted that in this portion the legal restriction refers only to that assigned by the MINTER Ordinance.

Thus, through the analysis of metric operations extracted from the GIS, the extensions of these legal rules are Table 3, in which the pre-established restrictions considered in this work and their respective areas are presented.

Table 3 - List of legal restrictions and their extensions

\begin{tabular}{c|c}
\hline RESTRICTION & AREA \\
\hline Water Collections (Ordinance MINTER 124/1980) & $194,093 \mathrm{~km} 2$ \\
\hline Airport Security (CONAMA 04/1995) & $142,583 \mathrm{~km} 2$ \\
\hline Areas of Permanent Preservation (METZGER, 2010) & $75,599 \mathrm{~km} 2$ \\
\hline Population Agglomerations (CETESB, 1994) & $35,189 \mathrm{~km} 2$ \\
\hline Highways (CETESB, 1994) & $4,258 \mathrm{~km} 2$ \\
\hline High Voltage Networks (ABNT / NBR 5422/1985) & $1,146 \mathrm{~km} 2$ \\
\hline
\end{tabular}

In Table 3 there are a large number of pre-established restrictions, which if added together would correspond to areas superior to the municipal extension, due to the fact that these restrictions overlap in several portions of the municipality, mainly to the north, as previously mentioned (Figure 4).

\section{FINAL CONSIDERATIONS}

The results obtained in the elaboration of this environmental planning, focused on landscape theory and the systemic approach, also taking into consideration the intrinsic characteristics of the 
environmental systems show that in the municipality of Anhumas the restrictions to the implantation of waste landfills exceed $70 \%$ of its territory, if we consider the high and very high degrees of fragility.

The complexity, extensiveness and comprehensiveness of the analysis in the process of choosing the landfill area in porous environments has provided significant advances by expanding and deepening the systemic understanding of the environmental issues, allowing the analysis of the conditioners of the landscape in an integrated way and the identification of the natural fragility of each environment.

The expansion of the analysis also elucidated incompatibilities of the legal norms and other legislation, engendered through governmental policies and actions and directed to the environmental management of solid waste.

It was verified that the rural economic activities in the municipality present great diversity, notably the sectors of sugarcane cultivation and the extensive cattle raising, besides the production of agricultural goods, such as: tomato, papaya, pepper, coffee, and others, which in general do not carry out their activities in a sustainable way.

The study of the municipality's natural attributes shows that there is a predominance of morphogenic processes on the ground, since the occupation and the land use, allied to the characteristics of the soil, provoke transformations in the modeling, represented by erosive processes that act on the slopes, with the development of ravines and gullies.

There are disparities between the ecodynamic units of potential instability (with part of their natural attributes preserved and / or conserved) and the ecodynamic units of emergent instability (anthropic systems). In areas where natural systems predominate, the incorporation of new areas of native vegetation in the form of riparian forests, legal reserves or ecological corridors, aim at the sustainability of productive ecosystems and the protection of natural resources. The environmental systems of the municipality of Anhumas show fragility with natural degradation processes, such as erosion on slopes, floods in areas with slopes lower than $2 \%$, located in the valley bottoms, and also the high soil permeability propitious to the infiltration of percolating liquids.

The environmental fragility with respect to the disposal of residues (solid, liquid or even gaseous) is accentuated in the predominant areas of Oxisols due to their high permeability and in the areas of the Argisols and Hydromorphs, due to their proximity to the water. Dense and disordered occupation compromises natural resources, unbalancing the flows of matter, energy and information in the geoenvironmental systems.

The way in which the productive activities are installed and distributed in this landscape causes impacts, such as the contamination of the water tables by the disposal of waste on the soil and by the aseptic pits, the accumulation of waste, water, air and visual pollution, damaging the population's quality of life.

The choice of the area for the sanitary landfill in the municipality of Anhumas (SP) revealed the importance of interdisciplinary knowledge in the process. In addition, it allowed the unveiling of new dimensions in the choice of the landfill area by potentiating new analytical instruments. Another aspect to be considered, in addition to the geoenvironmental characteristics of the municipality, is the implantation of sanitary landfills that do not ignore the possibility and necessity of establishing more sustainable uses, even in situations that show a medium degree of fragility, besides constant monitoring of the activities in the landfill.

\section{BIBLIOGRAPHIC REFERENCES}

ABNT, NBR. Associação Brasileira de Normas Técnicas. Projeto Eletromecânico de Linhas Aéreas de Transmissão de Energia Elétrica. Associação Bras. de Normas Técnicas: NBR 5422. Rio de Janeiro, 1985. 
ALMEIDA M. A.; et. al. Geologia do Oeste Paulista e áreas fronteiriças dos estados de Mato Grosso do Sul e Paraná. In: SBG, Congresso Brasileiro de Geologia, 31, Camboriú, V. 5: p. 2799-2812, 1980.

AMARAL, R. \& ROSS, J.L.S. As unidades ecodinâmicas na análise da fragilidade ambiental do Parque Estadual do Morro do Diabo e entorno, Teodoro Sampaio/SP. GEOUSP . São Paulo, nº 26, p. 59 - 78, 2009.

BERGAMO, E. P.; ALMEIDA, J. A. P. A importância da geomorfologia para o planejamento ambiental: um estudo do município de Fartura/SP. VI Simpósio Nacional de Geomorfologia, Goiânia - GO, 2006.

BERTALANFFY, L. VON. An Outiline of General Systems Theory. In: British Journal of Phylosophy of Science, n1, p. 139-164. London, 1950.

BERTRAND, C.; BERTRAND, G. Une géographie traversière: l'environnement à travers territoires et temporalités. Editora: Quae, 2002.

BERTRAND, G. Le paysage entre la Nature et la Société. In: La théorie du paysage en France 1974-1994. Champ Vallon, 1995. p. 88-108.

BERTRAND, G. Paisagem e geografia física global R. RA'E GA, Curitiba, n. 8, p. 141-152, 2004.

BOSCOV, M. E. G.. Geotecnia ambiental. São Paulo: Oficina de Textos, 2012.

BRASIL. Ministério do Interior - MINTER. Portaria n. ${ }^{0}$ 124. Estabelecem normas para a localização de indústrias potencialmente poluidoras junto às coleções hídricas. Brasília, 1980.

CETESB, Companhia de Tecnologia de Saneamento Ambiental. Manual para operação de resíduos sólidos: Disposição de lixo em vala. São Paulo, 1994.

CHRISTOFOLETTI, A. Morfologia estrutural. Notícia Geomorfológica, Campinas, v.12, n.24, p. 93-95, jun. 1972.

GUERRA, A. J. T.; MARÇAL, M. S. Geomorfologia Ambiental. 4. ed. Rio de Janeiro: Bertrand Brasil, 2012. LEITE, J. C. e ZUQUETTE, L. V. Atributos fundamentais à elaboração da carta de susceptibilidade à contaminação e poluição das águas superficiais. In: Congresso Brasileiro de Geologia de Engenharia. Anais... Rio de Janeiro: ABGE, p. 177-1823, 1996.

LEITE, J. C. Metodologia para elaboração da carta de susceptibilidade à contaminação e poluição das águas superficiais. Dissertação (Mestrado em Geotecnia) - Departamento de Geotecnia, Escola de Engenharia de São Carlos, Universidade de São Paulo. São Carlos. 1995. 192p.

MATEO RODRIGUEZ, J. M. Geografía de los paisajes. La Habana: Universidad de La Habana, 2000.

MATEO RODRIGUEZ, J. M. La concepcion sobre los paisajes vista desde la Geografia. UEM: Boletim de Geografia, v. 24, nº 1, p. 1-25, 2006.

MATEO RODRIGUEZ, J. M.; MAURO, A. C.; RUSSO, L. I.; SILVA, S. M. C.; BOVO, R.; ARCURI, P. E. M. e MARINHO, F. L. V. Análise da Paisagem como base para uma estratégia de organização geoambiental: Corumbataí (SP). Geografia, v. 20 (1), Rio Claro: UNESP, 1995, p. 81 - 129.

MATEO RODRIGUEZ, J. M.; SILVA, E. V. da; CAVALCANTI, A. P. B. Geoecologia das paisagens: uma visão geossistêmica da análise ambiental. Fortaleza: Editora UFC, 2004.

METZGER, J. P.. O Código Florestal tem base científica? Natureza \& Conservação. no 8, v. 1, p. 1-8, 2010. MONTAÑO, M.; RANIERI, V. E. L.; SCHALCH, V. FONTES, A. T.; CASTRO, M. C. A. A.; SOUZA, M. P. Integração de critérios técnicos, ambientais e sociais em estudos de alternativas locacionais para implantação de aterro sanitário. Eng Sanit Ambient, v. 17, n. 1, p. 61-70, 2012.

NAVEH, Z. Some remarks on recent developments in landscape ecology as a transdisciplinary ecological and geographical science. Landscape Ecology, v. 5, n. 2, p. 65-73, 1991.

NAVEH, Z.; LIEBERMAN, A.S. Landscape Ecology. Theory and Application. New York: Springer-Verlag, 1984, 105 p.

NUCCI, J. C. Ecologia e planejamento da paisagem, p. 50-63 in: SANTOS, DG dos; NUCCI, J. C. (orgs) Paisagens Geográficas: Um tributo a Felisberto Cavalheiro. Campo Mourão, Editora da FECILCAM, 2009.

NUNES, J. O. R. Uma contribuição metodológica ao estudo da dinâmica da paisagem aplicada à escolha de áreas para construção de aterro sanitário em Presidente Prudente. 2002. 211 f. Tese (Doutorado em Geografia) - Faculdade de Ciência e Tecnologia, Universidade Estadual Paulista. Presidente Prudente. 
OLIVEIRA, M. C. de. Paisagem, meio ambiente e planejamento. Revista do Instituto Geológico, v. 4, n. 1-2, p. 67-78, 1983.

OLIVEIRA, R. C. Escolha de área para aterro sanitário em meios porosos: o caso do Município de Anhumas - SP. 2015. 185 f. (Dissertação de Mestrado) - Mestrado em Meio Ambiente e Desenvolvimento Regional - MMADRE, Universidade do Oeste Paulista - UNOESTE.

RESOLUÇÃO CONAMA no 4, de 9 de outubro de 1995 Publicada no DOU no 236, de 11 de dezembro de 1995, Seção 1, página 20388 Estabelece as Áreas de Segurança Portuária - ASAs. Disponível em: <http:// www.mma.gov.br/port/conama/legiabre.cfm?codlegi=182>, Acesso em: 30 de julho de 2015.

ROSS, J. L. S. Análise empírica da fragilidade dos ambientes naturais e antropizados. Revista do Departamento de Geografia/FFLCH/USP, n. ${ }^{\circ}$ 8, p. 63-73, 1994.

ROSS, J. L. S. Geomorfologia: ambiente e planejamento. São Paulo: Editora Contexto, 9a edição, 2012.

SANTOS, R. F. Planejamento ambiental: teoria e prática. São Paulo: Oficina de textos, 2004.

TRESSOLDI, M.; CONSONI, J.A. Disposição de resíduos. In: Geologia de Engenharia. São Paulo: Associação Brasileira de Geologia de Engenharia, 1998.

TRICART, J. Ecodinâmica. Rio de Janeiro: IBGE/SUPREN, 1977.

TROPPMAIR, H. Sistemas, geossistemas, geossistemas paulistas e ecologia da paisagem. Rio Claro: edição do autor, 2004, 130 p.

ZUQUETTE, L. V.; PEJON, O. J.; SINELI, O. Methodology for specific engineering geological mapping for selection of sites for waste disposal. In: VII International IAEG Congress, Rotterdam. Anais... Balkerna, Rotterdam, 1994. p. 2481-2489. 